\title{
Exploring Civic Education as a Catalyst to Learner Transformation in Zambian Schools: A Glance on the Developed Civic Education Pedagogical Content Knowledge (CEPCK) Model
}

\author{
Setwin Mutau Mufalo ${ }^{1 *}$ \\ Mishikishi Secondary School, Masaiti, Zambia \\ ${ }^{*}$ Corresponding Author
}

\begin{abstract}
The main objective of this paper is to explore how Civic Education acts as a catalyst to learner transformation. The paper is structured in categories such as pedagogical content knowledge (PCK) model, and Civic Education pedagogical content knowledge (CEPCK) model among others. The author contends that in order for effective teaching and learner transformation to occur, teachers of Civic Education at both junior secondary school and senior secondary school should be knowledgeable with the learning outcomes which are specified in the school syllabi. In addition, Civic Education teachers should be equipped with relevant knowledge domains as outlined in the developed Civic Education pedagogical content knowledge model. Therefore, the developed Civic Education pedagogical content knowledge model may help different teaching/learning institutions in Zambia and beyond because it is a tool which can be used by administrators in various teaching and learning institutions to evaluate the competence levels of members of staff. In addition, the model may help teachers of Civic Education to deliver the subject effectively and impart learners with integrated knowledge, skills, values, dispositions and attitudes which may enable them not only to actively participate in community activities but also to be creative, live in harmony with others and be able to understand the contemporary society in which they live. It is therefore recommended that teachers of Civic Education in schools across the country should possess a variety of teacher knowledge as outlined in the developed Civic Education pedagogical content knowledge model (CEPCK) model in order to enhance not only effective delivery but also academic performance and learner transformation. In addition, the Ministry of General Education (MoGE), parents, teachers, administrators and other stakeholders should collaborate and come up with other strategies which can be used to enhance subject delivery and learners transformation. Also, universities, colleges of education and other various teacher training institutions in Zambia should adopt and include the developed Civic Education pedagogical content knowledge model in their curricular in order to equip Civic Education trainee teachers with knowledge domains as outlined in the developed model. Lastly, the researcher also recommends that the Ministry of General Education, the Curriculum Development Centre (CDC), Provincial Education Officers (PEOs) and District Education Board Secretaries (DEBS) and school administrators should ensure that schools adopt the use of the developed Civic Education pedagogical content knowledge model as well as
\end{abstract}

encouraging them to incorporate it during their Continuous Professional Development (CPD) activities.

Keywords: Civic Education, Civic Education Pedagogical Content Knowledge, Content Knowledge, Knowledge domains, Learner Transformation, Pedagogical Knowledge, Pedagogical Content Knowledge

\section{INTRODUCTION}

$T$ The content of this article is an extract from the Doctoral Thesis of the corresponding author who pursued his doctoral studies at the University of Zambia. The programme was offered by the University of Zambia in collaboration with Zimbabwe Open University (UNZA-ZOU). The programme was launched in August 2014 as an educational collaborative project commonly known as UNZA-ZOU following the acronyms of the two universities and it is still running (Simui, Kasonde-Ngandu, Cheyeka and Kakana, 2018) in Manchishi, Simui, Ndhlovu and Thompson (2020). Therefore, this paper explores how Civic Education acts as a catalyst to learner transformation. Also, it explores how teacher knowledge is of great paramount importance with regard to effective delivery and learner transformation as espoused in the developed Civic Education pedagogical content knowledge model.

\subsection{Context}

The education sector in Zambia has been undertaking curriculum reviews since independence. In 2013, the Ministry of Education (MoE) conducted curriculum reforms beginning from early childhood up to tertiary level and adult literacy (MoE, 2013). These education reforms which took place in 2013 led to the introduction of Civic Education at junior secondary school (grades 8 and 9) level which is integrated in a subject called Social Studies. But at senior secondary school level, Civic Education was first piloted in 2004 in some selected secondary schools in three provinces of Zambia (Lusaka, Central and Northern) whose first Grade 12 candidates sat for their final examination in 2006 while other provinces (Copperbelt, Eastern, North western, Southern and Luapula) were catered for in the second pilot phase in 2007 (Magasu, Muleya and Mweemba, 2020b). Furthermore, the 
revision of the curriculum in 2013 which was implemented in 2014 enhanced Civic Education both at junior secondary school and senior secondary school (grades 10 to 12). This was so in that the subject became compulsory across the country and the syllabi for both levels were also produced and later distributed in schools. It is also worth noting that Civic Education was there in the past but it was discontinued in 1978 as a result of alleged political pressure from the government during one party system of governance then which was under the presidency of the late Dr. David Kenneth Kaunda. Corresponding with these assertions, Kaumba, Kabombwe and Mwanza (2020) revealed that the curriculum review of 2013 made Civic Education a compulsory subject at senior secondary school level which was not the case before its revision. Besides, the subject was discontinued around 1978 (Kaumba et al., 2020) citing Muleya (2018a). Therefore, these reforms were meant to enhance the provision of quality education where learners are expected to acquire critical educational elements namely; worthwhile skills, appropriate attitudes and values as well as applicable knowledge which makes up competences (Mulenga and Kabombwe, 2019).

The general outcomes outlined in the junior secondary school Social Studies syllabus aims to enable learners to develop an understanding of the economic, political, civic, cultural, geographical and historical factors which influence social development (Ministry of Education, Science, Vocational Training and Early Education [MESVTEE], 2013). Also, the general outcomes as envisioned in the senior secondary school Civic Education syllabus intend to enable learners create an understanding of the political process and appreciation of good governance; promote positive attitudes, responsibilities, duties, obligations, freedoms and rights of a citizen in the learner; create awareness on the need for respect, promotion of democracy, human rights and freedoms and to develop an understanding of global issues (MESVTEE, 2013).

According to Muleya (2019: 2), the main aim of teaching and learning of Civic Education is "to equip learners with relevant knowledge, skills, values and dispositions which allow them to participate effectively in the community". Additionally, these competences which Civic education intends to equip learners with enable them to achieve an organized civil society (Serafico-Reyes, 2017). Since Civic Education is a subject which imparts learners with civic knowledge, civic skills and civic values (Mainde, Chola and Mpolomoka, 2021), it acts as catalyst to learner transformation. This is because through the teaching and learning of Civic Education, learners acquire relevant knowledge and have a deeper understanding of issues affecting the society and also skills for reflective and responsible action (Magasu et al., 2020b). Also, Muleya (2018a) as cited by Kaumba et al (2020) reinforces the above statement by stating that Civic Education has the capacity to transform learners' attitudes and habits that would help them as citizens to contribute effectively to the development of not only themselves but also their communities at large. This is because Civic Education as a subject is premised on transforming the mind-set of an individual for the common good of the community (Mainde et al., 2021). Therefore, right pedagogical practices in the teaching/learning of Civic Education can lead to learner transformation, social change and transformation of the society (Muleya, 2015). Furthermore, learner transformation can be enhanced by the teacher's fruitful utilisation of acquired knowledge as envisioned in the Civic Education pedagogical content knowledge model because it can help him/her to deliver the subject matter effectively.

\section{SIGNIFICANCE OF THIS PAPER}

This paper may help Civic Education teachers in schools across the country to be knowledgeable on how to enhance their subject delivery. Further, the paper may inform policy makers in the Ministry of General Education and other stakeholders on interventional measures which can enhance not only subject delivery by the teacher but also academic performance and learner transformation. Also, the paper may help administrators in different teaching and learning institution in Zambia and beyond to evaluate competences levels of their personnel through the use of the Civic Education pedagogical content knowledge (CEPCK) model. In addition, the paper may contribute additional knowledge to the existing literature in the field of Applied Science.

\section{LITERATURE REVIEW}

\subsection{Pedagogical Content Knowledge (PCK) Model (Shulman, 1986)}

Shulman's pedagogical content knowledge theoretical framework model is a two set Venn diagram which is a blend of pedagogical knowledge and content knowledge leading to the formation of an intersection which is pedagogical content knowledge as shown in figure 1.1 below.

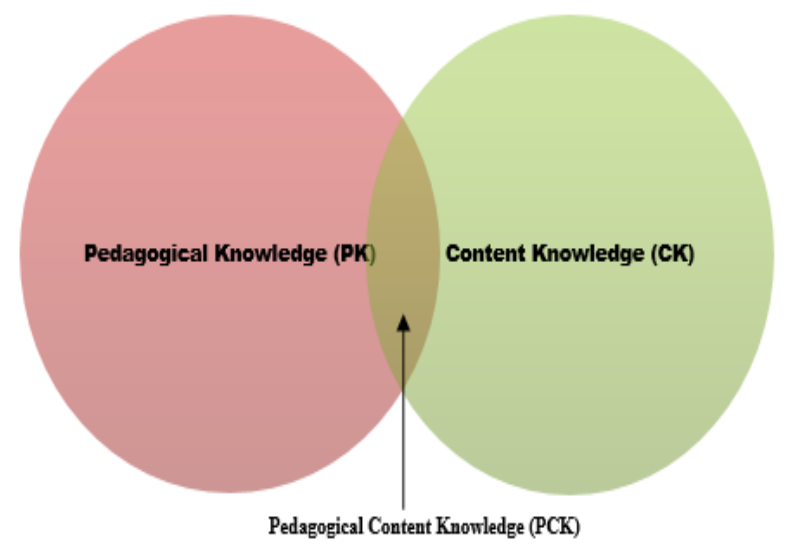

Figure 1.1: Pedagogical Content Knowledge Model (Shulman, 1986)

In 1986, Shulman addressed teacher knowledge in three dimensions which were; content knowledge, curriculum knowledge and pedagogical content knowledge. Integrating these knowledge domains, the teacher need to have enough subject matter knowledge, knowledgeable about the school 
curriculum as well as well braced with a variety of pedagogical skills for effective delivery. Consequently, the actual interpretation and transformation of the content by the teacher which integrates methods, strategies and techniques in order to enable the pupils to learn effectively is what is referred to as pedagogical content knowledge.

Later on Shulman development a new model where he added other components to make seven (7) knowledge domains namely; content knowledge, general pedagogical knowledge, curriculum knowledge, pedagogical content knowledge, knowledge of learners and their characteristics, knowledge of educational contexts and knowledge of educational philosophies, objectives and goals (Shulman, 1987). This position is also supported by Danisman and Tanisli (2017); Aksu, Metin and Konyalioglu (2014); Fernandez (2014); Saad, Barbar and Abourjeili (2012). However, many researchers have debated about these components of teaching knowledge and have proposed various models (Cochran, De Ruiter, and King, 1993; Grossman, 1990; Ma, 1999; Smith and Neale, 1989; Tamir, 1988) as cited by Danisman and Tanisli (2017). Consistent with this position, the notion of pedagogical content knowledge had been extended and criticised by many scholars including Shulman himself (2007); Segall (2004); van Driel, Verloop and Devos (1998); Cochran, King and De Ruiter (1993) as cited by Bachy (2014).

Nevertheless, Shulman (1986) model is a very important tool. In the current paper, this model has been modified by introducing a third variable i.e. Civic Education in the two set Venn diagram which has produced a three set Venn diagram with an intersection which is Civic Education pedagogical content knowledge.

\section{CIVIC EDUCATION PEDAGOGICAL CONTENT KNOWLEDGE MODEL}

The infusion of the variable (Civic Education) into Shulman's pedagogical content knowledge has resulted into the formation of a three set Venn diagram with seven (7) categories of teacher knowledge with an intersection being Civic Education pedagogical content knowledge (CEPCK). Therefore, the produced knowledge domains are content knowledge (CK), pedagogical knowledge (PK), Civic Education content knowledge (CECK), pedagogical content knowledge (PCK), Civic Education knowledge (CEK), Civic Education pedagogical knowledge (CEPK) and Civic Education pedagogical content knowledge (CEPCK). Figure 1.2 shows the developed Civic Education pedagogical content knowledge model which can be used to measure the teacher's competence or effectiveness. Also, if well harnessed, it could be ideal for the enhancement of teacher delivery and learner transformation in the contemporary society.

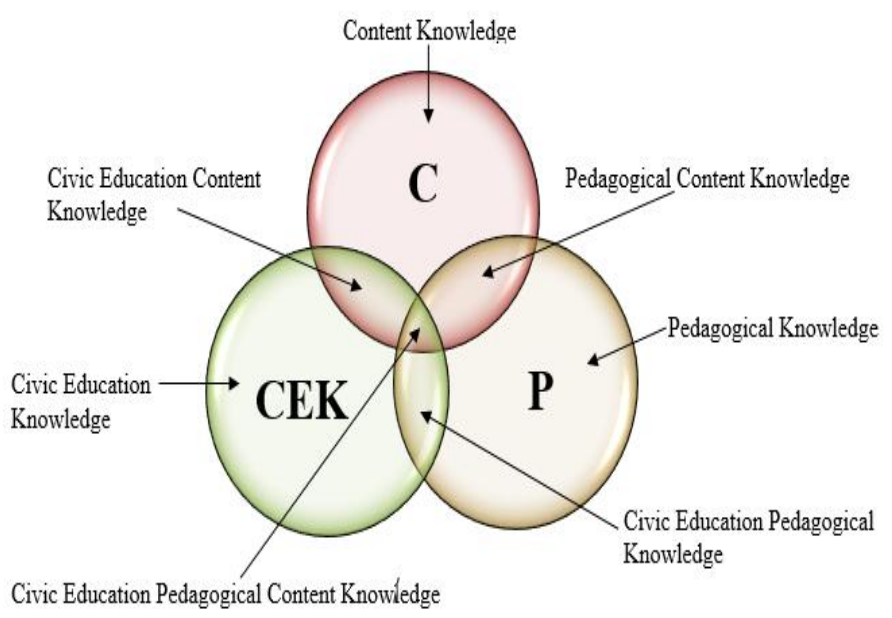

Figure 1.2: Civic Education Pedagogical Content Knowledge Model

In order for effective teaching and learner transformation to occur, Civic Education teachers must be well equipped with a variety of hypothetical domains as highlighted above. Therefore, effective teaching is the teaching that successfully achieves the learning objectives or outcomes by the pupils as identified by the teacher (Bhowmik, Roy and Banerjee, 2013). Below is a detailed explanation of all the seven (7) knowledge domains as highlighted in the developed Civic Education pedagogical content knowledge model.

\subsubsection{Pedagogical Knowledge}

This is one of the dimensions of hypothetical domains which teachers should be acquainted with during the teaching and learning of Civic Education. Pedagogical knowledge is the methodological knowledge on how to present the subject matter to learners in the classroom. It includes strategies, techniques and methods used in the teaching and learning process. It is important also to understand the meaning of these concepts (methods, strategies and techniques) in teaching. Methods are ways of instruction in which data is conveyed to learners. For instance, it can be either through learner centred methods or teacher centred methods. A strategy is a general plan of action which the teacher follows in order to achieve the learning outcomes of a lesson which include methods to use, teaching and learning aids and evaluation devices. A technique is a specific action selected by a teacher which is deemed necessary for the implementation of the teaching process such as question and answer, class discussions, teacher exposition, brainstorming among others. Sadly, a number of teachers still have challenges in selecting a method, technique or an appropriate strategy which suits the concept to be taught (Kestiani, Riandi and Rochintaniawati, 2018). This aspect can lead to failure by learners to acquire relevant Civic Education profile dimensions hence affecting both their academic performance and transformation.

Furthermore, pedagogical knowledge includes the knowledge of class management, developing a lesson plan and evaluations in order to enable students to learn (Aksu, Metin 
and Konyalioglu, 2014; Bachy, 2014). Since knowledge of evaluation devices is part of pedagogical knowledge, it is very important for Civic Education teachers to be knowledgeable with varieties of assessment/evaluation devices such as written or oral tests, class exercises, assignments and paused lesson questions etc. It enables both the Civic Education teacher and learners to know their teaching and learning deficiencies so that remedial measures can be instituted. This position agrees with the opinion of Bhowmik, Roy and Banerjee (2013) who stated that assessment devices are important because they provide appropriate feedback to the teacher for bringing desirable modification in his or her methods and materials of teaching including justifying the need of bringing alteration in setting of instructional objectives. Therefore, utilisation of a variety of assessment devices by the teacher enhances both content assimilation by learners and indeed their transformation.

Additionally, pedagogical knowledge encompasses knowledge of classroom management which is also a vital skill required to be acquired by Civic Education teachers. Classroom management refers to "the creation of a regular and safe classroom environment that helps students learn, and it focuses on the development and implementation of effective teaching and learning strategies" (Calik, 2012) as cited by (Topal, 2020: 225). Class management include the strategies and materials which the teacher may use to have a calm, pleasant, and propitious class environment for students' learning, the good relationship between the students and the teacher; the introduction of appropriate materials, standards, and procedures for the class; the teachers' ability to guide a class and give instructions; and the creation of a motivating and organised learning environment (Cevallos and Soto, 2020). It is important to note that student achievement is also influenced by the teacher's strategies of classroom management (Gess-Newsome, 2002). These strategies may include silence of the teacher and continuing looking at troublesome learners, memorising student names, keeping learners busy with class activities and with-it-ness. With-itness refers to "a teacher's awareness of what is going on in the classroom behaviours before they get out of line" (Chandra, 2015: 14). The author further adds that Theorist Jacob Kounin stressed the importance of "with-it-ness," which is the idea that the teacher should know what happens in their classroom at all times. Further, the other strategy which teachers need to employ which should be agreed by learners is to set up class rules and traffic patterns which allow students to move around the classroom, enter and leave it to save time and minimise disruption (Popescu, 2014). Sadly, most teachers fail to manage their learners' behaviour due to cohesive techniques and limited class management skills. According to B. F. Skinner's Behaviour Modification Theory, behaviour is shaped through systematic reinforcement and punishment has limited effects (Chandra, 2015). Therefore, misbehaviour occurs when needs of learners are not met and democratic classrooms support effective learning (Chandra, 2015).
It is also important to note that a teaching strategy which may enable some learners to understand a certain lesson topic may not do so to other learners. Hence, triangulation in terms of teaching strategies and techniques within a single lesson should be encouraged because it mitigates possible shortcomings which may arise during lesson delivery. Additionally, utilisation of a variety of relevant strategies and techniques during the teaching/learning process may trigger enthusiasm among learners due to the conducive interpersonal relationship which might be created. Therefore, acquisition of a variety of pedagogical skills by Civic Education teachers enables them to deliver their lessons effectively and in a logical manner for the benefit of learners. Consistent with this view, Kathirveloo, Puteh and Matematik (2014) posited that acquisition of relevant pedagogical knowledge by the teacher helps him/her to have the capacity to transform the knowledge taught to the students in a way that it can be easily understood. In this regard, every teacher must be equipped with appropriate pedagogical knowledge in the implementation of the teaching and learning process (Rahmi, 2018). Also, the teacher's pedagogical knowledge can be enhanced through continuous professional development (CPD) activities. These activities are very important because teachers share knowledge on different pedagogical skills necessary for effective subject delivery. This is the reason why the study by Mainde et al (2021) recommended that schools should strengthen Continuous Professional Development (CPD) activities such as Lesson Study Cycles, Cluster Meetings among others because they reinvigorate pedagogical skills of Civic Education teachers which are necessary tools for effective teaching and learning. Thus sufficient acquisition of pedagogical knowledge by the teacher is key to student achievement (Mufalo, Mulubale, Muleya and Simui, 2021).

\subsubsection{Content Knowledge}

Under Content knowledge domain, a Civic Education teacher must have a better understanding of the subject matter knowledge to avoid delivery challenges and being out of context. Content Knowledge refers to the amount and organization of knowledge in the mind of the teacher (Shulman, 1986). In other words, content knowledge is the subject knowledge which every teacher must understand as outlined in the teaching syllabus. This view is in line with the statement of Aksu et al (2014) who said that teachers must understand all the knowledge in their subject. In this regard, the subject knowledge to be taught and studied by learners must be that which is outlined in the school syllabus drawn from the education curriculum. Hence, the content knowledge is what every Civic Education teacher must be knowledgeable with for effective delivery of relevant knowledge, skills, values, attitudes and dispositions necessary for learner transformation. It should be put on record that it is not only learners having challenges and misconceptions of the subject matter knowledge even teachers too (Kathirveloo et al., 2014). Hence, Civic Education teachers should endeavour to assimilate the subject knowledge to avoid delivery challenges which may result into classroom distracters emanating from 
learners. The fact that some teachers do not have enough content knowledge may hinder students to learn the subject well (Aksu et al., 2014). But teachers who are conversant with the subject matter knowledge help learners to learn well than when the subject content knowledge is poor (Kind \& Chan, 2019). Therefore, Civic Education teachers must understand the concepts and topics they teach very well for easy delivery and comprehension by learners (Department for Education, 2015). In light of this, it is very important for Civic Education teachers to be aware that only a desirable amount of content material is supposed to be covered within a specified period of time as outlined in the syllabus (Bhowmik et al., 2013).

\subsubsection{Pedagogical Content Knowledge}

This concept was introduced by Shulman in 1986 (Rahmi, 2018). Pedagogical content knowledge is an amalgam of content and pedagogy (Kind and Chan, 2019). It refers to teacher's interpretations and transformations of subject-matter knowledge in the context of helping student learning (Rahmi, 2018; Kathirveloo et al., 2014). In other words, it is the interpretation and transformation of relevant subject content by the teacher as outlined in the syllabus using a variety of instructional strategies in order to enable pupils learn. Further, Geddis (1993) as cited by De Miranda (2008) described pedagogical content knowledge as a set of attributes that helps teachers or someone to transfer the knowledge of content to learners or others. In line with this position, pedagogical content knowledge represents the blending of content and pedagogy into an understanding of how particular topics, problems are organised and represented to the diverse interests and abilities of learners and presented for instruction (Shulman, 1987). This knowledge helps the teacher with regard to the transformation of his or her subject-matter knowledge of the academic discipline in order to cater for the varied interests, backgrounds, and capacities of learners (Wilson, Shulman and Richert, 1987) in Deng (2007).

Pedagogical content knowledge plays an important role in the teaching and learning process because it involves teacher's competences in delivering the conceptual approach, relational understanding and adaptive reasoning of the subject matter (Kathirveloo et al., 2014). Therefore, teacher quality depends on the teacher's pedagogical content knowledge acquisition (Mufalo et al., 2021). Thus, acquiring pedagogical content knowledge (PCK) of sufficient depth and quality in order to impact student positively lies at the heart of the teacher's education and professional development (Kind and Chan, 2019). Also, PCK can be developed by teacher's overtime and through experience on how to teach certain content in a certain way to improve learners' understanding (Sagir, Kucukaydin, Berry and Mulhall, 2012) as cited by Kestiani et al (2018). It also important to point out that most successful teachers who are effective in teaching are those who have flexible PCK that adapts quickly in classroom settings as they see learners' varied responses to planned instruction (Kind and Chan, 2019). Lack of PCK negatively influence the teacher's effective teaching and learning process in the classroom (Kathirveloo et al., 2014).

\subsubsection{Civic Education Knowledge}

Civic Education knowledge is the variety of literature, resources, materials or information which individuals, families and the society as a whole are endowed with which are relevant for their well-being as citizens. This type of resources is that which is not structured or prescribed in the Civic Education school syllabus. But it is the resource or literature which is important to learners and also useful to Civic Education teachers for effective delivery of the subject in order to enable students acquire profile dimensions which are necessary components in the process of learner transformation. Examples of such resources are the parents, families, traditional authorities, religious institutions, civil society organisations, the media that is, print and electronic media such as televisions, newspapers, the internet and radios among others. These resources play a very important role in imparting learners and other members of the society with civic knowledge, civic competences and civic values (Kaumba et al., 2020). This is because Civic Education is not limited to formal structures of the school system alone but goes beyond (Muleya, 2018a). The information in these structures outside the school environment can either be on issues such as respect for the rule of law, good governance, upholding family values, respect for human rights, unity in diversity or tolerance etc as long as the information is relevant to learners and the general citizenry. Ultimately, these activities outside classroom environment makes learning real as learners incorporate theories learnt during classroom lessons into practice (Mainde et al., 2021). Therefore, Civic Education should be deemed as multi-dimensional and praxis in nature. This means that the subject cuts across different spheres of life and is action oriented.

\subsubsection{Civic Education Content Knowledge}

The combination of Civic Education knowledge and the content knowledge forms Civic Education content knowledge. In other words, this is the amalgamation of Civic Education content outlined in the school syllabus and other relevant resources or literatures which are not prescribed in the Civic Education syllabus. Also, it can be described as an amalgam of knowledge from formal structures of the school system and the knowledge from informal structures outside the school system. Both categories of knowledge bases are necessary because they act as conduits in the delivery of civic knowledge, civic skills, civic values and civic dispositions.

\subsubsection{Civic Education Pedagogical Knowledge}

This is the interweaving of Civic Education knowledge and pedagogical knowledge. Also, Civic Education pedagogical knowledge is a product resulting from the mixture of teaching methods, strategies, techniques, evaluations, class management and teaching resources. Therefore, teachers of Civic Education should be knowledgeable with Civic 
Education pedagogical skills and other necessary resources which may not be prescribed hence the need to encourage them to be eclectic and resourceful in order to help pupils learn.

\subsubsection{Civic Education Pedagogical Content Knowledge}

This is a product/intersection of the combination of content knowledge, pedagogical knowledge and Civic Education knowledge. In other words, it is the amalgamation of all the knowledge domains namely; content knowledge, pedagogical knowledge, pedagogical content knowledge, Civic Education knowledge, Civic Education content knowledge and Civic Education pedagogical knowledge. Therefore, all Civic Education teachers should be knowledgeable with the information highlighted in the amalgam to enable them interpret and transform the subject matter knowledge as prescribed in the syllabus through the integration of pedagogical skills in order to help pupils learn. It is important to note that no matter how a teacher is conversant with the subject matter if he/she has limited pedagogical knowledge, specific learning outcomes may not be achieved. This is because students have different learning abilities for instance; some pupils are slow learners while others are fast learners. Hence, teachers should be equipped with a variety of teaching skills to meet the demand of each and every learner. Therefore, Civic Education teachers have the responsibility to make sure that all pupils are given equal opportunity to learn because they have the right to education despite their diverse interests and learning abilities. This assertion is in line with the government policy document of 1996, 'Educating Our Future' where it is clearly stated that education is for all learners (MoE, 1996). It is the reason why the Disability Act of 1996 was enacted to cater and provide for the learning needs of slow learners, fast learners and differently abled persons among others in the light of discrimination practices against them in different environments which included the school (MoE, 2013).

\section{CONCLUSION}

It is clear from the information highlighted above that the gist of effective teaching and learning is embedded in teacher knowledge as outlined in the Civic Education pedagogical content knowledge model. In addition, effective teaching which results in learner acquisition of expected learning outcomes or competences as prescribed in the Civic Education syllabus is also dependent upon different stakeholders such as parents, teachers, administrators and other personnel in the Ministry of General Education who must collaborate not only for the advantage of learners but also the society as a whole. Also, the Ministry of Higher Education, Ministry of General Education and Curriculum Development Centre (CDC) should ensure that the developed Civic Education pedagogical content knowledge model is incorporated into Civic Education curriculum/course outline. If the aforementioned aspects are not put into consideration, the teaching and learning process can be affected which in turn may also affect the subject deliver, academic performance of learners as well as learner acquisition of relevant Civic Education profile dimensions which are necessary tools and key for their survival.

\section{IMPLICATIONS}

1. When Civic Education teachers effectively interweave the content knowledge and pedagogical knowledge in the classroom, it helps learners to grasp, understand, reason, transform and reflect on the body of knowledge presented to them (Shulman, 1986).

2. The developed Civic Education pedagogical content knowledge model if well harnessed by different teaching/learning institutions in Zambia and beyond, can be a useful tool which can be employed to evaluate the competence levels of members of staff.

3. This model may help teachers of Civic Education to teach the subject effectively and impart learners with integrated knowledge, skills, values, dispositions and attitudes which may enable them not only to actively participate in community activities and understand the contemporary society in which they live but also the world as a whole.

4. The model can also be used by policy makers in the Ministry of General Education and other stakeholders to come up with interventional measures which can be used to enhance teacher effectiveness, academic performance and learner transformation.

\section{RECOMMENDATIONS}

Basing on the conclusions drawn by the researcher, the following are the recommendations;

1. There is need for teachers of Civic Education in schools across the country to possess a variety of teacher knowledge as outlined in the Civic Education pedagogical content knowledge model (CEPCK) model in order to enhance not only effective delivery but also academic performance and learner transformation.

2. The Ministry of General Education (MoGE), parents, teachers, administrators and other stakeholders should also collaborate and come up with other strategies which can be used to enhance subject delivery and learners transformation.

3. Universities, colleges of education and other various teacher training institutions in Zambia should adopt and include the developed Civic Education pedagogical content knowledge model in their curricular in order to equip Civic Education trainee teachers with knowledge domains as outlined in the developed model.

4. The Ministry of General Education, the Curriculum Development Centre (CDC), Provincial Education Officers (PEOs) and District Education Board Secretaries (DEBS) and school administrators should 
ensure that schools adopt the use of the developed Civic Education pedagogical content knowledge model as well as encouraging them to include it during their Continuous Professional Development (CPD) activities.

\section{REFERENCES}

[1] Manchishi, P. C., Simui, F., Ndhlovu, D., \& Thompson, C. L. (2020). Tracing the Experiences of an Inaugural Postgraduate Distance Education Alumni cohort of the University of Zambia. Multidisciplinary Journal of Language and Social Sciences Education, 3 (1), 131-157.

[2] Ministry of Education. (2013). The Zambia Education Curriculum Framework. Lusaka: Curriculum Development Centre.

[3] Mulenga, I. M., \& Kabombwe, Y. M. (2019). A CompetencyBased Curriculum for Zambian Primary and Secondary Schools: Learning from Theory and some Countries around the World. International Journal of Education and Research, 7(2), 117-130.

[4] Ministry of Education, Science, Vocational Training and Early Education. (2013). Social Studies Syllabus Grades 8-9. Lusaka: Curriculum Development Centre.

[5] Ministry of Education, Science, Vocational Training and Early Education. (2013). Civic Education Syllabus Grades 10-12. Lusaka: Curriculum Development Centre.

[6] Muleya, G. (2019). Curriculum Policy and Practice of Civic Education in Zambia: A Reflective Perspective. In The Palgrave Handbook of Citizenship and Education; Peterson, A., Stahl, G., Soong, H., Eds.; Cham, Switzerland: Palgrave Macmillan.

[7] Serafico-Reyes, N. M. A. (2017). Civic Competency in Junior High School-Mapping through the Content and Performance Standards of the Philippine Social Studies (Araling Panlipunan) Curriculum. In Proceedings of the 2nd Asian Education Symposium (AES 2017), 467- 472.

[8] Mainde, D., Chola, D. K., \& Mpolomoka, D. L. (2021). Interrogating Civic Education Pedagogies that Stimulate Political Participation in Selected Secondary Schools in Zambia. International Journal of Research and Innovation in Social Science (IJRISS), 5(2), 269-279.

[9] Magasu, O., Muleya, G., \& Mweemba, L. (2020b). Pedagogical Challenges in Teaching Civic Education in Secondary Schools in Zambia, International Journal of Science and Research (IJSR),9(3), 1483-1488.

[10] Kaumba, C., Kabombwe, Y. M., \& Mwanza, C. (2020). Civic Competences: What does an Outcomes Based Curriculum mean for a Civic Education Teacher in Zambia? International Journal of Education and Research, 8(6), 87-104.

[11] Muleya, G. (2015). The teaching of civic education in Zambia: An examination of trends in the teaching of civic education in Schools. Doctoral thesis, University of South Africa.

[12] Shulman, L. S. (1986). Those who understand: Knowledge growth in teaching. Educational Researcher, 15(2), 4-14.

[13] Danişman, S., \& Tanişli, D. (2017). Examination of Mathematics Teachers' Pedagogical Content Knowledge of Probability. Malaysian Online Journal of Educational Sciences, 5(2), 18-34.

[14] Aksu, Z., Metin, M., \& Konyalioglu, A. C. (2014). Development of the Pedagogical Content Knowledge Scale for Pre-Service Teachers:The Validity and Reliability Study. Mediterranean Journal of Social Sciences, 5(20), 1365-1377.

[15] Fernandez, C. (2014). Knowledge base for Teaching and Pedagogical Content Knowledge (PCK): Some useful models and implications for teachers' training. Problems of Education in the $21^{\text {st }}$ century, vol., 60, 79-100.

[16] Saad, M. M., Barbar, A. M., \& Abourjeili, S. A. R. (2002). TPACK-XL Framework for Educators and Scholars: A theoretical Grounding for Building Pre-service Teachers ICT Knowledge Base. Conference Paper, 1-21.

[17] Bachy, S. (2014). TPDK, a New Definition of the TPACK Model for a University Setting. European Journal of Open, Distance and e-Learning, 17(2), 15-39.
[18] Bhowmik, M., Roy, B. B., \& Banerjee, J. (2013). Role of Pedagogy in Effective Teaching. Basic Research Journal of Education Research and Review, 2(1), 1-5.

[19] Kestiani, J., Riandi, R., \& Rochintaniawati, D. (2018). Analysis Technological Pedagogical Content Knowledge Ability of Teachers. Advances in Economics, Business and Management Research, vol. 212, p. 270-273.

[20] Topal, M., \& Sezen-Gultekin, G. (2020). Gamification in Classroom Management. Available from: https://www.DOI: 10.4018/978-1-7998-1408-5.ch012. [Accessed on 03/11/2020]

[21] Cevallos, L. F. E., \& Soto, S. T. (2020). EFL Classroom Management. MEXTESOL Journal, 44(2), 1-11.

[22] Gess-Newsom, J. (2002). Pedagogical Content Knowledge: An Introduction and Orientation. In Gess-Newsome, J and Lederman, N. G. (1999) (Eds.). PCK and Sciences Education. Netherlands: Kluwer Academy Publishers.

[23] Chandra, R. (2015). Classroom Management for Effective Teaching. International Journal of Education and Psychological Research (IJEPR), 4(4), 13-15.

[24] Popescu, T. (2014). Classroom management strategies and techniques: A perspective of English teacher trainees. Available from: https://www.DOI: 10.29302/jolie.2014.7.10. [Accessed on 03/11/2020]

[25] Kathirveloo, P., Puteh, M., \& Matematik, F. S. (2014). Effective Teaching: Pedagogical Content Knowledge. Malaysia: Universiti Pendidikan Sultan Idris.

[26] Rahmi, E. (2018). The Analysis of Pedagogical Content Knowledge of Teacher Candidates. Advances in Economics, Business and Management Research, vol. 57, p. 604-609.

[27] Mufalo, S. M., Mulubale, S., Muleya, G., \& Simui, F. (2021). Challenges faced by Combined Schools in Masaiti district which hinders the provision of Quality Education. International Journal of Research and Innovation in Social Science (IJRISS), 5(3), 146154.

[28] Kind, V., \& Chan, K. K. H. (2019). Resolving the amalgam: connecting pedagogical content knowledge, content knowledge and pedagogical knowledge. International Journal of Science Education, 1-15, DOI: 10.1080/09500693.2019.1584931

[29] Department for Education, (2015). Statutory guidance science in the national curriculum programmes of study. Available on: https://dera.ioe.ac.uk/22953/1/National\%20curriculum\%20in\%20 England \%20science\%20programmes\%20of\%20study\%20$\% 20$ GOV_UK.pdf. [Retrieved on 01/11/2020]

[30] De Miranda, M. A. (2008). Pedagogical Content Knowledge and Engineering and Technology Teacher Education: Issues for thought. Journal of the Japanese Society of Technology Education, 50(1), 17-26.

[31] Deng, Z. (2007). Knowing the subject matter of a secondaryschool science subject. Journal of Curriculum Studies, 39(5), 503535.

[32] Muleya, G. (2018a). Civic education versus citizenship education: Where is the point of convergence? Journal of Lexicography and Terminology, 1(2), 125-148.

[33] Ministry of Education. (1996). Educating Our Future. Lusaka: Government Printers. 